\title{
METODE DEWAN HISBAH PERSIS DALAM BER- ISTIDLÂL DENGAN HADIS: STUDI FATWA TENTANG TAMBAHAN RAKA'AT MAKMUM YANG MASBUQ
}

\author{
Solehudin \& Widiana Rismawati \\ Fakultas Ushuluddin UIN Gunung Djati Bandung \\ Jl. AH. Nasution No. 105, Cibiru, Bandung \\ E-Mail: Suryakancana1991@gmail.com
}

\begin{abstract}
Istidlal is asked for directions or look for clues (evidence) of the sources agreed that Al-Qur'an, Sunnah, ijma 'and qiyas and still there is no contradiction in it. Hisbah Council is an institution that is in the body of the Islamic Society organizations (Persis) in charge of examining the issues that require decisions. The institute is always to give an answer to the arguments of the foundation, which in the view is always different with other organizations in Indonesia. This research is descriptive qualitative data sources Thuruq book Al-istinbath hisbah Council of the Islamic Society, as well as the data collected from various sources and processed. Based on the results of the study authors, it can be concluded that the views of the Board hisbah the Hadith, is that the Hadith or Sunnah can be made in the determination of a legal argument, and can serve as the Qur'an in determining clean and unclean, and mandatory or sunnah. Council conclusions hisbah determine which methodology istinbath its air-Istidlâldengan Hadisyang therein mentioned Qaeda-Qaeda received and not received by the Board in determining the quality of Hadith hisbah for a decision. And Council hisbah not wear Hadith about masbūqīn congregation gets compassionate priest in count one rak'ah, because it is considered Da'eef, and the congregation is left behind al-Fatihah not counted raka'at, means must be added that the omission of the raka'at.
\end{abstract}

Keywords: Fatwa;Hadis; Istidlal; Masbuq.

\begin{abstract}
Abstrak
Istidlâl adalah meminta petunjuk atau mencari petunjuk (dalil) dari sumber-sumber yang telah disepakati yaitu Alquran, Sunnah, Ijma' dan qiyas maupun yang masih ada pertentangan di dalamnya. Dewan Hisbah adalah lembaga yang berada dalam tubuh organisasi Persatuan Islam (Persis) yang bertugas meneliti masalah yang membutuhkan keputusan. Lembaga ini selalu memberi jawaban dengan dalil-dalil landasannya, yang di pandang selalu berbeda dengan oraganisasi yang lainnya yang ada di Indonesia. Penelitian ini bersifat deskriptifkualitatif dengan sumber data buku Thuruq Al-istinbath Dewan Hisbah Persatuan Islam, serta tehnik pengumpulan data dari berbagai sumber untuk kemudian diolah. Berdasarkan hasil penelitian penulis, dapat diambil kesimpulan bahwa Pandangan Dewan Hisbah terhadap hadis, adalah bahwa hadis atau sunnah dapat di jadikan hujjah dalam menentukan suatu hukum, dan dapat berfungsi seperti Alquran dalam menentukan halal dan haram, dan wajib atau sunnah. Dewan Hisbah menentukan rumusan metodologi istinbath-nya yaitu ber-Istidlâldengan Hadisyang di dalamnya disebutkan qaidah-qaidah yang diterima dan yang tidak diterima oleh Dewan Hisbah dalam menentukan kualitas hadis untuk sebuah keputusan. Dan Dewan Hisbah tidak memakai hadis tentang makmum masbuq mendapat ruku' imam di hitung satu raka'at, karena dinilai dha'if, dan makmum yang ketinggalan al-fatihah tidak dihitung satu raka'at, artinya harus di tambah raka'at yang tertinggalnya tersebut.
\end{abstract}

Kata Kunci: Fatwa;Hadis; Istidlal; Masbuq.

\section{A. PENDAHULUAN}

Hadis atau sunnah Rasulullah adalah merupakan dasar tasyri' sesudah al-Quran dan merupakan sumber dari aneka Ilmu Pengetahuan Islam. Semua amal yang dikerjakan Muhammad Saw. dalam sifat dan fungsi beliau sebagai Rasulullah Saw, menjadi hukum umum yang wajib kita ikuti. ${ }^{1}$ Sebagaiman firman Allah dalam QS. AlHasyr : 7 : "Apa yang diberikan Rasul

\footnotetext{
${ }^{1}$ Barmawie Umarie. Status Hadis Sebagai Dasar
} Tasyri'. (Sala: Penerbit. AB. Sitti Sjamsiyyah. 1963). kepadamu, Maka terimalah. dan apa yang dilarangnya bagimu, Maka tinggalkanlah. dan bertakwalah kepada Allah. Sesungguhnya Allah Amat keras hukumannya". 2

Dalam kaitannya dengan sumber hukum Islam terdapat perbedaan yang sangat besar antara Al-Quran dan Hadis Nabi, seperti

\footnotetext{
${ }^{2}$ Kementrian Agama RI. Al-Quran Tajwid dan Terjemahnya. (Jakarta: PT. Sygma Examedia Arkanleema. 2007).
} 
dikemukakan Syeikh Abdul Wahab Khalaf ${ }^{3}$, nash Al-Quran seluruhnya bersifat qath'i alwurud, artinya kalau Al-Quran diyakini sepenuhnya oleh kaum muslimim, tanpa kecuali sebagai wahyu yang datang dari Allah. Sementara hadis yang bersifat qath' $i$ al-wurud bagi hadis mutawatir yang tidak dapat di sangkal keshahihannya dan zhanni al-wurud bagi hadis yang tidak berkualitas mutawatir. Dan salah satu diantara petunjuknya (dilalah-nya) itu kadang qath' $i$ atau zhanni. Kalau tidaklah ada sunnah yang dijadikan hujjah untuk kaum muslimin, maka tidak akan ada peraturan-peraturan yang akan dijalankan yaitu apa-apa yang diwajibkan oleh Al-Quran itu. Sunah yang menerangkan wajib diikuti, karena bersumber dari Rasul. Dirawikan dari Rasul dengan jalan mempergunakan Qath'i atau Zhan yang kuat. Oleh karena itu apabila seseorang meragukan kebenaran Al-Quran sebagai wahyu dan sebagai sumber hukum yang pasti maka akan mengakibatkankan kekufuran, sedangkan jika meragukan suatu hadis sebagai sesuatu yang betul-betul berasal dari ucapan Rasul, maka keraguannya tidak sampai pada akibat yang seperti itu.

Menghadapi realita diatas fakta perbedaan pemahaman terjadi pada masa sahabat saja, bahkan membias sampai kepada tabi'in, tabi'ut tabi'in, bahkan sampai sekarang. Banyak diantara para ulama yang mempelajari Al-Quran, dan Al-Hadis, tidak diragukan pula kebenaran al-Quran yang muthlaq, sehingga para ulama yang jujur tidak berani sembarangan mengambil keputusan dalam menafsirkan Al-Quran, akan tetapi selalu terdapat perbedaan dalam memahami sunnah Rasul, terutama dalam menentukan hukum.

Peran ulama saat ini sangatlah penting untuk membahas masalah problematika ummat saat ini , karena merekalah yang mempunyai kapabilitas dalam pengetahuan Islam. Ulama di Indonesia khususnya yang tergolong dalam organisasi masyarakat (Ormas) yang dikenal masyhur seperti Nahdatul Ulama (NU), Persatuan Islam

\footnotetext{
${ }^{3}$ Syeikh Abdul Wahab Khalaf, Ilmu Ushul Fikih. (Jakarta: PT Rineka Cipta, 1995), 41.
}

(Persis), dan Muhammadiyah. Dimana NU, Persis, Muhammadiyah ini mempunyai metode masing-masing dalam menetapkan sebuah hukum, karena perbedaan dalam memahami hadis Nabi dan metode yang diambil berbeda-beda maka hasil keputusannya pun berbeda pula. Misalnya Nahdhatul Ulama (NU) mempunyai metode dengan pengambilan qaul (pendapat imam madzhab) yang kemudian disebut dengan metode qauly, merupakan metode utama yang digunakan dalam menyelesaikan masalah keagamaan oleh lembaga Lajnah Bahtsul Masail, terutama yang menyangkut hukum fikih, dengan merujuk pada kitabkitab imam madzhab yang empat ( Hanafi, Maliki, Hanbali, dan Syafi'i), yang lebih didominasi oleh Madzhab Syafi'i. Muhammadiyah yang mempunyai Lembaga Majlis Tarjihnya dalam menentukan sebuah hukum dan mempunyai metode tersendiri dengan merujuk langsung kepada Al-Quran dan As-Sunnah, dan dicari yang lebih kuat untuk menentukan sebuah hukum, begitu pula dengan Persis yang di kenal selalu berbeda dengan ormas yang lainnya, bahkan ada sebagian masyarakat yang memandang bahwa Persis cukup keras dalam pemikirannya, namun Persis dikenal juga dengan lembaga yang tidak canggung dengan istilah ijtihad, karena menurut Persis pintu ijtihad masih terbuka. Jika NU dengan Lajnah Bahtsul Masail nya, dan Muhammadiyah dengan Majlis Tarjih nya, maka Persis mempunyai lembaga yang disebut dengan Dewan Hisbah yang tercatat dalam Qanun Asasi-Qanun Dakhili Persis Bab V Pasal 59 yang berfungsi sebagai dewan pertimbangan, pengkajian syara' dan fatwa dalam jam'iyyah, yang mempunyai metode dalam menetapkan sebuah hukum, khususnya dalam menentukan metode (manhaj) dalam ber-Istidlâl dengan Hadis.

Diantara perbedaan pandangan dalam pemahaman hadis adalah tentang orang yang masbuq.Salah satu hadis nya adalah Apabila kamu datang untuk shalat padahal

\footnotetext{
${ }^{4}$ Imam Yahya. Dinamika Ijtihad NU. Semarang: Walisongo Press, cet. I, 2009. Hal 47. "Keputusan Muktamar NU ke-32".
} 
kamu sedang sujud, maka bersujudlah, dan jangan kamu hitung sesuatu (satu raka'at) dan siapa yang mendapatkan ruku', berarti ia mendapatkan satu ruku' (raka'at) dalam shalat (nya)." (HR. Abu Daud, 1:207)

Sebagian ulama ada yang berpendapat bahwa makmun yang mendapatkan imam sedang ruku', maka ia berarti mendapatkan satu raka'at, ${ }^{6}$ ada pula yang tidak mendapat satu raka'at atau harus di tambah lagi satu raka'at karena ketinggalan Al-Fatihah. Kebanyakan masyarakat, di Indonesia khususnya, memakai hadis tersebut dan apabila masbuq dan mendapatkan ruku' maka tidak di tambah satu raka'at, sedangkan masyarakat Persis paling berbeda dengan yang lainnya yaitu dengan menambah satu raka'at, karena ketinggalan membaca AlFatihah.

Salah satu organisasi yang mencoba memberi pemahaman terkait hal diatas adlah Dewan Hisbah Persis. Diantara hasil ijtihad Dewan Hisbah Persis hingga saat ini masih kuat berpegang pada dalil Alquran dan hadishadis shohih. Melihat bahwa Persis adalah salah satu organisasi yang selalu berbeda dengan organisasi yang lainnya, dan selalu yakin dengan fatwa yang dikeluarkannya, maka hal yang menarik untuk dijadikan kajian adalah bagaimana metode (manhaj) dalam ber-istidilâl bil hadis yang dijadikan pedoman Dewan Hisbah Persatuan Islam.

Untuk itulah penelusuran terhadap yang digunakan Dewan Hisbah dalam menyelidiki sebuah hukum melalui hadis, menjadi hal yang menarik untuk dibahas terkait tema "Tambahan Raka'at Makmum yang Masbuq".

\section{B. PEMBAHASAN}

\section{Dewan Hisbah Persis dan Kajian Hadis}

Pada permulaan abad ke-20 bahwa sesungguhnya jauh sebelum tanggal 12 September 1923 (berdirinya PERSIS) telah ada suatu kelompok kajian ajaran Islam dan ajaran yang berlaku secara faktual. Mereka menamakan kelompok penelaahnya itu

\footnotetext{
${ }^{5}$ Lidwa Pusaka i-Software-Kitab 9 Imam Hadits

6 A. Zakaria. Alhidayah Edisi Kompilasi 1,2,3. (Garut: Ibn Azka Press), 138.
}

dengan nama Persatuan Islam, ada juga yang memberi nama Permufakatan Islam. Jadi sebelum Tahun 1923 nama Persatuan Islam itu bukan nama sebuah organisasi melainkan nama kelompok penelaah (study club) dan inilah sebagai cikal bakal atau embrio Lembaga Dewan Hisbah.

Sebagaimana diungkap di atas bahwa Persatuan Islam yang sejak awal didirikan merupakan sebuah kelompok tadarus atau kelompok kajian dari orang-orang yang prihatin terhadap kondisi aqidah, ibadah dan akhlak ummat, yang tenggelam dalam berbagai perbuatan bid'ah, syirik dan munkarat lainnya,

Dewan Hisbah merupakan lembaga khusus yang ada dalam organisasi Persatuan Islam. Kedudukannya bersifat khusus dan hampir sama dengan lembaga Dewan Tafkir, yang berfungsi membahas perkembangan pemikiran Islam. Hanya saja, Dewan Hisbah lebih terfokus pada perkembangan masalahmasalah hukum Islam. ${ }^{7}$

Produk hukum Dewan Hisbah ditetapkan dalam persidangan ${ }^{8}$ yang dihadiri oleh Ulama Dewan Hisbah. Sidang Dewan Hisbah terdiri dari:pertama, Sidang Lengkap yaitu yang diikuti oleh seluruh pimpinan dan anggota Dewan Hisbah, kedua, Sidang Terbatas yaitu yang diikuti oleh seluruh pimpinan dan sebagian anggota Dewan Hisbah, dan ketiga, Sidang Komisi yang diikuti oleh seluruh anggota komisi. ${ }^{9}$

Setelah melakukan persidangan, barulah Dewan Hisbah mengeluarkan fatwa-fatwa yang berkaitan sesuai dengan hasil persidangan, kemudian disebarluaskan hasil dari keputusannya itu kepada anggotanya.

\section{Metode Dewan Hisbah Persis dalam Ber-Istidlâl dengan Hadis}

Dewan Hisbah sebagai Majelis Ulamayang berkewajiban meneliti hukum

\footnotetext{
${ }^{7}$ Dani Hidayat. Persatuan Islam Offline Versi 2.0.

${ }^{8}$ Sidang adalah musyawarah Dewan Hisbah untuk mengkaji, mendiskusikan dan memecahkan persoalan hukum Islam yang berkembang di tengah masyarakat sehingga menghasilkan keputusan hukum yang disepakati bersama.

${ }^{9}$ Rafid Abbas, Ijtihad Persatuan Islam. Tela'ah atas Produk Ijtihad PERSIS tahun 1996-2009, 98-99
} 
Islam, juga berkewajiban untuk melakukan pengawasan dalam pelaksanaan dan teguran atas pelanggaran terhadap suatu hukum, telah menentukan manhaj(metode) dalam memutuskan atau mengambil keputusan hukum, dari sejak 2001 dan di sahkan pada tahun 2006. Dalam thuruq al-istinbath ini Dewan Hisbah merumuskan tiga metodologi utama, yaitu: 1) Ber-Istidlâldengan AlQuran, 2) Ber-Istidlâldengan Hadis, 3) Ijtihad atas masalah yang tidak ada nash. Dalam karya tulis ini penulis akan fokus pada pembahasan Istidlâl Bil-Hadis-nya. Dasar utama yang digunakan Dewan Hisbah adalah al-Quran dan hadis shahih.

Adapun rumusan metodologi Dewan Hisbah dalam Ber-Istidlâl dengan Hadis, adalah sebagai berikut: ${ }^{10}$

1). Menggunakan Hadis Shahih dan Hasan dalam mengambil keputusan hukum.

2) Menerima Qaidah : الآحَادِيْثُ الضَّعِيْفَةُ “Hadis-hadis dha'if satu sama lain adalah saling menguatkan". Dengan catatan apabila dha'if-nya hadis tersebut dari segi dhabth (hafalan) dan tidak bertentangan dengan al-Quran atau hadis lain yang shahih. Adapun jika dlaif-nya dari segi 'Adalah seperti kadzab (pendusta), yadha'ul hadis (memalsukan hadis), fisqur-rowi atau tertuduh dusta, maka qaidah tersebut tidak dipakai.

3). Tidak Menerima Qaidah

$$
\text { اَلْحَدِيْثُ الضَّعِيْفُ يُعْمَلُ فِ فَضَائِلِ ألاعْمَالِ }
$$

"Hadis dha'if dapat diamalkan dalam hal keutamaan."

Karena keutamaan amal juga termasuk sendi-sendi agama yang harus berdasarkan hadis shahih. Masih banyak hadis-hadis shahih yang menunjukkan keutamaan amal.

4). Menerima hadis shahih sebagai tasyri'(penetapan syari'at) yang mandiri, sekalipun tidak merupakan bayan dari alQuran, seperti dalam masalah 'aqiqah dan pengurusan jenazah.

${ }^{10}$.Aceng, Zakaria. Thuruq Al-Istinbath. Dewan Hisbah Persatuan Islam, 67-69
5). Menerima Hadis Ahad sebagai dasar hukum selama hadis tersebut shahih, termasuk masalah-masalah yang menyangkut 'aqidah.

6). Hadis Mursal Shahabi dan Mauquf bi Hukmil Marfu' dipakai sebagai hujjah selama sanadhadis tersebut shahih dan tidak bertentangan dengan hadis lain yang shahih.

7). Hadis Mursal Tabi'iy dijadikan hujjah apabila hadis tersebut disertai qorinah yang menunjukkan ittishal-nya hadis tersebut.

8). Menerima Qaidah

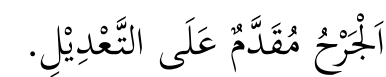

"Anggapan Jarh (cacat terhadap seorang perawi) harus didahulukan daripada anggapan 'adil/tsiqot'.

9). Menerima kaidah tentang Shahabat:

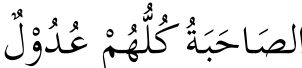

"Shahabat-shahabat Nabi itu semuanya dinilai adil (dalam periwayatan hadis)".

10) Riwayat orang yang suka melakukan tadlis (menyamarkan cara menerima hadis dari guru) diterima jika ia menerangkan bahwa apa yang ia riwayatkan itu jelas Shigat Tahammul-nya (kata yang digunakan dalam menerima hadis dari guru) menunjukkan ittishal (tersambung/menerima secara langsung), seperti menggunakan kata haddatsanî (menceritakan hadis secara langsung tanpa perantara).

\section{Aplikasi Dewan Hisbah dalam Ber- Istidlâl dengan Hadis tentang Hadis Masbuq mendapat ruku' Imam}

Aplikasi Dewan Hisbah dalam ber-istidlâl dengan hadis, salah satunya adalah tentang menambah raka'at bagi seseorang yang masbuq dengan hadis yang menjadi rujukan utamanya adalah hadis apabila masbuq mendapatkan imam sedang ruku'.

Pertama-tama Dewan Hisbah menyebutkan perbedaan argumentasi yang terjadi tentang makmum yang mendapat ruku' di hitung raka'at atau tidak. Sebagaimana Aceng Zakaria menuturkan, dalam hal ini 
terjadi dua pendapat yang berbeda, diantaranya: 1) ada yang berpendapat bahwa makmum yang mendapatkan imam sedang ruku', sebelum imam menegakkan tulang punggungnya maka ia berarti mendapatkan satu raka'at, artinya tidak ditambah raka'at dengan hadis-hadis yang menjadi sandarannya, 2) ada juga yang berpendapat tidak termasuk satu raka'at, artinya perlu ditambah raka'atnya mengingat membaca Al-Fatihah adalah wajib, dengan hadis-hadis yang menjadi pijakannya. ${ }^{11}$

Diantara dalil-dalil yang dijadikan argumentasi oleh kelompok pertama, sebagai berikut:

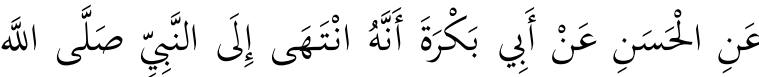

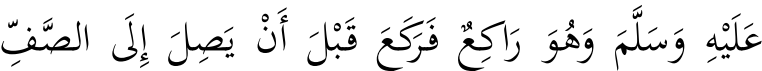

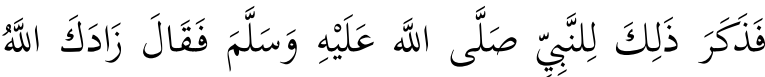

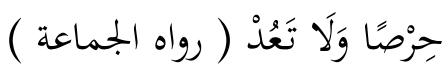

Dari al-Hasan, dari Abu Bakrah, sesungguhnya ia sampai kepada Nabi saw. ketika sedang ruku', lalu ia ruku' sebelum sampai ke shaf, kemudian ia menceritakan hal itu kepada Nabi saw. Maka beliau bersabda, "Semoga Allah menambahkan semangat terhadapmu dan janganlah engkau ulangi'. HR. Al-Jama'ah ${ }^{12}$

Pada hadis ini diterangkan dengan jelas bahwa Abu Bakrah menjadi makmum masbuq mendapatkan imam (Nabi saw.) sedang ruku', lalu dia ruku' bersama imam, dan Nabi tidak memerintahkannya menambah raka'at lagi.

$$
\begin{aligned}
& \text { عَنْ أَبِ هُرَيْرَة قَالَ قَالَ رَسُولُ اللَّهِ صَلَّى اللَّه عَلَيْهِه وَسَلَّمَ }
\end{aligned}
$$

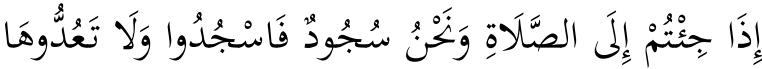

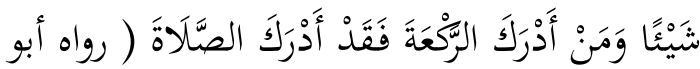

Dari Abu Hurairah, ia berkata, "Rasulullah saw. bersabda, 'Jika kamu mendatangi salat, padahal kami sedang sujud, maka sujudlah dan janganlah kamu

11 A. Zakaria. Al-Hidayah. Edisi Kompilasi, Garut: Ibnu Azka Press2006), 137.

${ }^{12}$ Amien Mukhtar. Syarh Makmum Masbuq Mendapat Ruku Imam. t.t. menghitungnya satu rakaat (mendapatkan rakaat). Dan barangsiapa mendapatkan rakaat (ruku), maka dia mendapatkan salat'." ( H.R. Abu Daud). ${ }^{13}$

Hadis ini mengandung makna bahwa jika makmum masbuq mendapatkan ruku' bersama imam, sebelum imam bangkit dari $r u k u$ '-nya, dia mendapatkan raka'at tersebut. Makna ini sebagaimana disebutkan dalam riwayat Abu Daud lainnya dengan lafal:

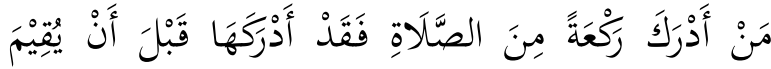

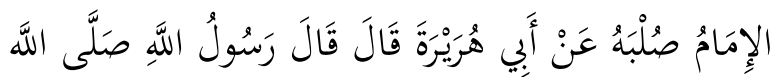
عَلَيْهِه وَسَلَّمَ

Dari Abu Hurairah, Rasulullah berkata, "Barang siapa menyusul satu rakaat dari salat maka ia telah menyusul rakaat itu sebelum imam meluruskan punggungnya." 14

Kemudian diperkuat pula oleh keterangan Zaid bin Wahb: "Aku keluar bersama Abdullah (Ibnu Mas'ud) dari rumahnya menuju masjid. Ketika kami sampai di tengah masjid, imam ruku'. Lalu Abdullah bertakbir dan ruku', dan aku ruku' bersamanya. Kemudian dalam kedaan ruku' kami berjalan sehingga sampai shaf, ketika orang-orang mengangkat kepala mereka. Setelah imam menyelesaikan salatnya, aku berdiri, karena aku menganggap tidak mendapatkan rakaat. Namun Abdullah memegangi tanganku dan mendudukanku, kemudian berkata, 'Sesungguhnya engkau telah mendapatkan (raka'at)'.,'15

Demikianlah Dewan Hisbah menyebutkan hadis-hadis yang menjadi argumentasi kelompok pertama. Kemudian Dewan Hisbah memaparkan dalil-dalil yang menjadi argumentasi kelompok kedua, diantaranya yaitu:

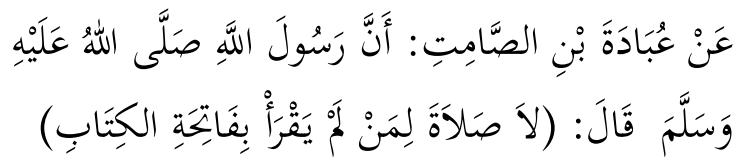

\footnotetext{
${ }^{13}$ Aceng Zakaria, dengan mengutip Kitab Sunan Abi Daud. Cet. I, (Mesir: Musthafa al-Babi al-Halabi).

${ }^{14}$ Lihat, Majalah As-Sunnah, Edisi 03/Tahun VII/2003

${ }^{15}$ Juz'ul Qiraah Khalfal Imam, al-Muhalla 2/274278; Nailul Authar 2/511-514
} 
Dari 'Ubadah bin Ash Shamit, bahwa Rasulullah shallallahu 'alaihi wasallam bersabda: "Tidak ada shalat bagi yang tidak membaca Faatihatul Kitab (Al Fatihah)." HR. Al-Jama'ah. ${ }^{16}$

$$
\begin{aligned}
& \text { عَنْ أَبِي هُرَيْرَةَ: أَنَّ رَسُولَ اللَّهِ صَلَّى اللهُ عَلَيْهِه وَسَلَّمَ دَخَلَ }
\end{aligned}
$$

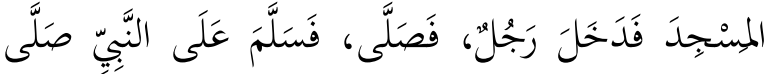

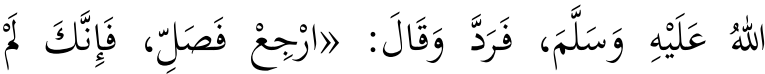

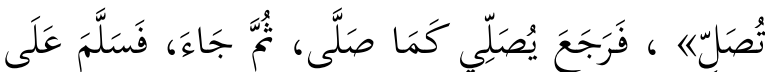

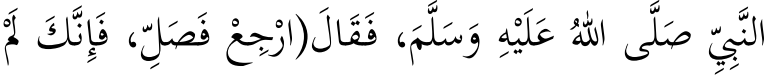

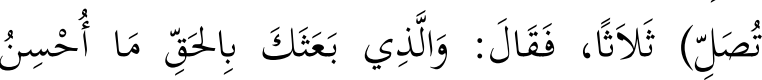

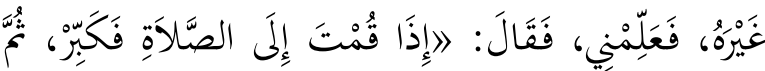

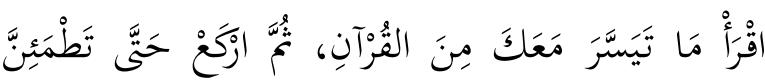

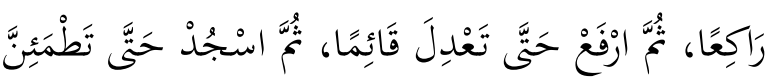

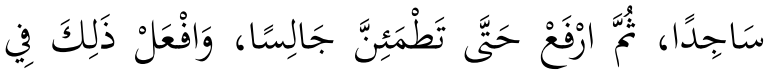

$$
\begin{aligned}
& \text { صَلالَتِكَ كُلِّهَاها رواه البخاري، فتح الباري 2: } 277
\end{aligned}
$$

Dari Abu Hurairah, bahwa Rasulullah shallallahu 'alaihi wasallam masuk ke masjid, lalu ada juga seorang laki-laki masuk Masjid dan langsung shalat kemudian memberi salam kepada Nabi shallallahu 'alaihi wasallam. Beliau menjawab dan berkata kepadanya, "Kembalilah dan ulangi shalatmu karena kamu belum shalat!" Maka orang itu mengulangi shalatnya seperti yang dilakukannya pertama tadi kemudian datang menghadap kepada Nabi shallallahu 'alaihi wasallam dan memberi salam. Namun Beliau kembali berkata: "Kembalilah dan ulangi shalatmu karena kamu belum shalat!" Beliau memerintahkan orang ini sampai tiga kali hingga akhirnya laki-laki tersebut berkata, "Demi Dzat yang mengutus Tuan dengan hak, aku tidak bisa melakukan yang lebih baik dari itu. Maka ajarkkanlah aku!" Beliau lantas berkata: "Jika kamu berdiri untuk shalat maka mulailah dengan takbir, lalu bacalah apa yang mudah buatmu dari Al

\footnotetext{
${ }^{16}$ Wawan Shofwan dkk.Makmum Masbuq Mendapat ruku' Imam. Tim sekretariat Dewan Hisbah Persatuan Islam. Bandung. 2006. Dengan mengutip Kitab Nailul Author II, 229.
}

Qur'an kemudian rukuklah sampai benarbenar rukuk dengan thuma'ninah (tenang), lalu bangkitlah (dari rukuk) hingga kamu berdiri tegak, lalu sujudlah sampai hingga benar-benar thuma'ninah, lalu angkat (kepalamu) untuk duduk hingga benar-benar duduk dengan thuma'ninah. Maka lakukanlah dengan cara seperti itu dalam seluruh shalat (rakaat) mu." H.r. al-Bukhari, Shahih al-Bukhari, I:263, No. 724; Muslim, Shahih Muslim, I:298, No. 397; Abu Daud, Sunan Abu Daud, I:226, No. 856; atTirmidzi, Sunan at-Tirmidzi, II:103, No. 303; an-Nasai, Sunan an-Nasai, II:124, No. $884 .{ }^{17}$

Kemudian dengan keterangan hadis tersebut, Dewan Hisbah berpendapat bahwa hadis tersebut bisa ditentukan tolak ukur raka'at shalat, sebagiamana disebutkan bahwa secara mantuq-nya (makna tersurat) menetapkan bahwa raka'at itu terdiri atas qiyam, baca al-Fatihah, ruku', i'tidal ruku', sujud, duduk diantara dua sujud, dan sujud.

Setelah mengumpulkan hadis-hadis yang menjadi rujukan kelompok pertama dan kedua, Dewan Hisbah dalam makalahnya tentang MasbuqMendapat Ruku'Imam yang ditulis oleh Tim SekretariatDewan Hisbah pada bulan April 2006, menanggapi dari hadis-hadis tersebut di atas, dengan meneliti hadisnya, baik dari segi sanad maupun matan dengan merujuk berbagai kitabHadis, kitab Syarh al-Hadis, kitab Jarh dan Ta'dil, kitab Rijal al-Hadis, dan Kitab yang lainnya, sebagai sumber rujukan Dewan Hisbah dalam mencari dalil yang akan diterapkan di masyarakat Persis khususnya dan masyarakat luas pada umumnya.

Tanggapan Dewan Hisbah mengenai hadis tentang peristiwa Abu Bakrah, dengan merujuk Kitab 'Aunul Ma'bud jilid III halaman 103, dinyatakan:

Pada hadis Abu Bakrah, tidak ada keterangan bahwa, pertama ia dipandang telah mendapatkan raka'at itu, kedua ia tidak diperintah pula untuk mengulanginya.

Dengan demikian, hadis tersebut (sampai kata wala ta'ud) tidak ada hubungannya

17 Amien Mukhtar. Syarh Makmum Masbuk Mendapat Ruku' Imam. Dengan mengutip Kitab Fathul Bari, II, 227. 
dengan masalah makmum masbuq mendapatkan raka'at atau tidak. Karena itu Imam as-Syaukani berkata, "Pada hadis itu tidak ada keterangan yang dapat dijadikan dalil pendapat kelompok pertama, karena sebagaimana ia tidak diperintah mengulangi shalat tidak ada keterangan pula bahwa Nabi menganggap ia mendapatkan raka'at itu. Sedangkan du'a Nabi 'semoga Allah menambah semangat" tidak berarti ia mendapatkan rakaat itu."

Namun pada riwayat Al-Bukhari dalam kitabnya Juz al-Qiraah Khalfal Imam, terdapat perintah dari Nabi kepada Abu Bakrah untuk menambah raka'at yang terlewat itu dengan kalimat:

$$
\text { صَلِّ مَا أَدْرْكْتَ وَاقْضِ مَا سَبَقَكَكَ }
$$

"Lakukanlah apa yang kamu dapati dan sempurnakanlah apa yang terlewat". ${ }^{18}$

Perintah Nabi kepada Abu Bakrah ini menunjukkan bahwa:

a. makmum yang masbuq mendapatkan imam (Nabi saw.) sedang ruku', lalu dia ruku' bersama imam, maka dipandang ketinggalan rakaat

b. yang menjadi tolok ukur makmum mendapatkan satu raka'at bukan ruku'nya imam.

Tanggapan kedua masih tentang riwayat Abu Bakrah, bahwa riwayat Abu Bakrah ini sesuai dengan keumumuman perintah yang senantiasa dikemukakan oleh Nabi kepada orang (makmum) yang masbuq.

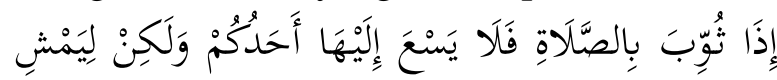

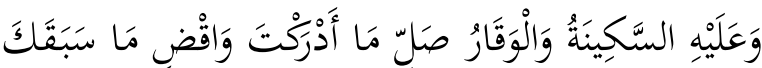

"Apabila shalat telah dilaksanakan, janganlah seseorang berjalan dengan tergesa-gesa mendatangi salat itu, tetapi hendaklah ia tenang. Lakukanlah apa yang kamu dapati dan sempurnakanlah apa yang terlewat". H.R. Muslim, dan pada riwayat Al-Bukhari dengan redaksi:

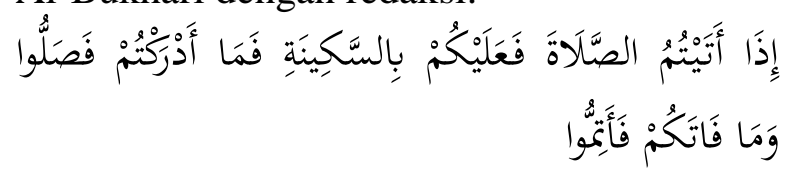

${ }^{18}$ Wawan, Shofwan dkk. Makmum Masbuq Mendapat ruku' Imam. 2006
"Apabila kalian mendatangi salat, hendaklah tenang. Apa yang dapat kalian susul maka lakukanlah dan apa yang tertinggal maka sempurnakanlah". ${ }^{19}$

Apabila pemaknaan hadis Abu Bakrah itu tidak demikian, maka hadis tersebut akan menyalahi keumuman perintah tersebut. Sehubungan dengan masalah tersebut dengan mengutip dari Kitab Bukhori Juz Al-Qir'atu Khalafal Imam, Abu Hurairah menyatakan:

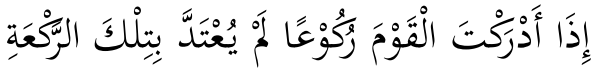

“Apabila kamu menyusul jama'ah shalat sedang ruku', maka raka'at itu jangan dihitung".

Pernyataan tersebut semakin mempertegas sikap shahabat terhadap masalah makmum masbuq mendapati imam sedang ruku'. Adapun penilaian matruk terhadap Ma'qil dari al-Azdi pada pernyataan Abu Hurairah, tidak akan mempengaruhi sikap para sahabat tersebut, karena penilaian al-Azdi itulah yang matruk (ditinggalkan). Ibnu Hajar menyatakan: "Sangkaan al-Azdi bahwa Ma'qil matruk adalah keliru". ${ }^{20}$

Menurut argumentasi kelompok pertama, makna hadis Abu Bakrah sejalan dengan riwayat Abu Daud, dengan lafal:

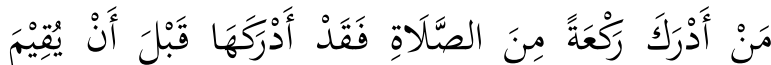
الإِمَامُ صُلْبَهُ

Dari Abu Hurairah, ia berkata, "Barangsiapa menyusul satu rakaat dari salat maka ia telah menyusul rakaat itu sebelum imam meluruskan punggungnya. "21

Kemudian denganmengutip dari Kitab Sunan Abu Daud, ini tanggapan dari Dewan Hisbah:"hadis Abu Daud sebagaimana disebutkan dalam majalah di atas tidak kami temukan dalam riwayat Abu Daud kecuali menggunakan redaksi":

\footnotetext{
${ }^{19}$ Wawan, Shofwan dkk. Makmum Masbuq Mendapat ruku' Imam. tim sekretariat dewan hisbah persatuan islam. bandung. 2006.

${ }^{20}$ Ibnu Hajar Al-Asqolany. Taqribut Tahdzib,

${ }^{21}$ Majalah As-Sunnah, Edisi 03/Tahun VII/2003
} $1: 540$ 


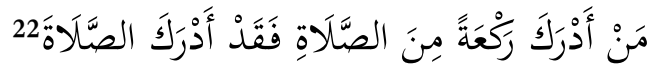

Kemudian Dewan Hisbah menyebutkan bahwa, redaksi seperti itu justru kami temukan pada riwayat Ad-Daraquthni (Lihat, Sunan ad-Daraquthni, Dar al-Fikr, 1994, juz 1, hal. 272, pada kitabus shalahbab man adrakal imam qabla iqamati shulbihi faqad adrakas shalah, hadis No. 1298) Namun hadisnya dha'if dilihat dari aspek sanad dan matan. Pada sanad-nya terdapat rawi bernama Qurrah bin Abdurrahman. Abu Zur'ah berkata, "Hadis-hadis yang diriwayatkannya munkar" Ad-Daraquthni berkata, "Tidak kuat dalam periwayatan hadis" (Lihat, Tahdzibul Kamal, XXIII:583584). Kemudian dilihat dari segi matan, hadis ini dikategorikan mudraj fil matan (terdapat tambahan kalimat pada matannya), yakni kalimat qabla an yuqimal imamu shulbahu. Karena pada riwayat Ma'mar, Malik, Yunus, Ibnu Juraij, Sufyan bin Uyainah, dan al-Auza'i tidak ada kalimat itu. Semuanya hanya meriwayatkan sampai kalimat faqad adrakaha. ${ }^{23}$

Mengenai hadis riwayat Abu Daud, sebagai berikut:

عَنْ أَبَي هُرَيْرَةَ قَالَ قَالَ رَسُولُ اللَّهِ صَلَّلَى اللَّهُ عَلَيْهِهِ وَسَلَّمَ

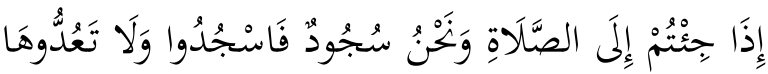

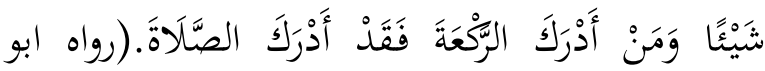

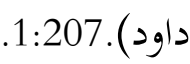

Dari Abu Hurairah dia berkata; Rasulullah shallallahu 'alaihi wasallam bersabda: "Jika kalian datang untuk menunaikan shalat, sedangkan kami dalam keadaan sujud, maka ikutlah bersujud, dan janganlah kalian menghitungnya satu raka'at, dan barangsiapa mendapatkan ruku', berarti dia telah mendapatkan satu ruku' (raka'at) dalam shalat (nya). ${ }^{24}$

22 Sunan Abu Daud, (Beirut:Dar al-Fikr, 1990), jilid I, 251, pada kitabus shalah bab man adraka minal jum 'ah rak'atan, hadits No. 1121

\footnotetext{
${ }^{23}$ Wawan, Shofwan, dkk. Makmum Masbuq Mendapat Ruku' Imam, tim sekretariat dewan hisbah persatuan islam. bandung. 2006.

${ }^{24}$ Aceng Zakaria, dengan mengutip Kitab Sunan Abi Daud. Cet. I, Mesir, Musthafa al-babi al-halabi
}

Selajutnya, Aceng Zakaria menyebutkan bahwa pada hadis di atas terdapat rawi yang bernama Yahya bin Abi Sulaiman al-Madani. Menurut Amir Al-Mu'minin di dalam hadis ialah: Muhammad bin Ismail al-Bukhori dalam (kitab) "Al-Qira'at Khalfal Imam" disebutkan bahwa Yahya bin Abi Sulaiman yang ini derajatnya Munkar Hadis. Menurut yang lainnya hadis tersebut telah diriwayatkan sendirian oleh Yahya bin Abi sulaiman, sedang dia itu tidak kuat hafalannya. Dengan kata lain bahwa hadis tersebut susunan sanad-nya itu Mursal. ${ }^{25}$

Tidak dapat dijadikan dalil bahwa makmum masbuq jika dapat melakukan $r u k u$ ' bersama imam, ia telah mendapatkan raka'at itu walaupun tidak membaca alFatihah. Karena kata rak'ah pada riwayatriwayat di atas maknanya adalah raka'at secara keseluruhan yang di dalamnya terdapat qiyam (berdiri), qiraah (bacaan AlFatihah), ruku', i 'tidal (berdiri) setelah ruku', dan sujud, bukan makna ruku' secara khusus (posisi ruku'). Adapun makna rak'ah untuk menunjukkan posisi ruku' di dalam shalat itu sudah merupakan makna majazi (kiasan) dan bukan makna sebenarnya. Oleh karena itu, untuk mengartikan rak'ah dengan arti posisi ruku' memerlukan qarinah (keterangan lain). Seperti pada hadis riwayat Muslim dari AlBarra bin Azib yang dikutip dari Kitab 'Aunu Al-Ma'bud, 3:148 berikut ini:

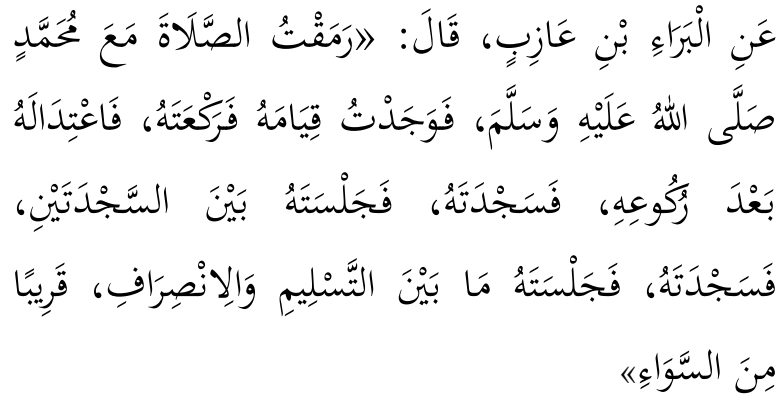

Dari al-Bara' bin 'Azib dia berkata, "Aku memperhatikan shalat bersama Muhammad Shallallahu'alaihiwasallam, lalu aku mendapatkan berdirinya, rukuknya, i'tidalnya setelah rukuk, sujudnya, duduknya antara dua sujud, sujudnya, dan duduknya antara dua salam, dan keluarnya (dari shalat) semuanya adalah mendekati sama."

\footnotetext{
${ }^{25}$ A. Zakaria. Al-Hidayah, 140.
} 


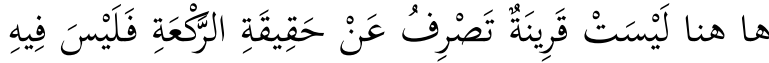

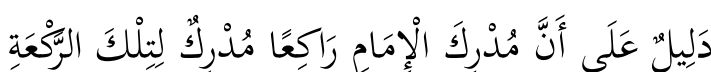

Disini tidak terdapat qarinah (alasan) apapun yang memalingkan arti hakiki raka'at (kepada arti lain, yakni ruku'), maka hadis tersebut bukan dalil, bahwa yang mendapatkan imam dalam keadaan ruku' berarti mendapat satu raka'at.

Hadis di atas berbeda dengan hadis yang diriwayatkan oleh Imam Bukhori dari Abu Hurairah:

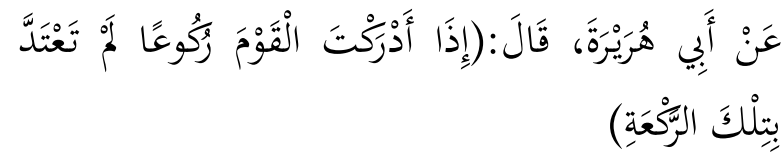

Dari Abu Hurairah r.a bahwasannya ia berkata: "Jika engkau mendapatkan suatu kaum sedang ruku', maka tidak terhitung raka'at. HR. Bukhori Juz Al-Qira'tu Khalfal Imam (Lihat, 'Aunul Ma'bud, 3:146)

Dengan ini, lanjut Aceng Zakaria, jelaslah kelemahan alasan-alasan pendapat jumhur yang menyatakan bahwa siapa saja yang mendapatkan imam dalam keadaan ruku', termasuk raka'at bersamanya (imam) dan bisa dihitung satu raka'at sekalipun tidak mendapat bacaan (Fatihah) sedikitpun. ${ }^{26}$

Selanjutnya, mengenai hadis shahabat Ibnu Mas'ud, Dewan Hisbah menyatakan: Di dalam beberapa riwayat, baik berupa qaul (perkataan) maupun amal (perbuatan) diterangkan bahwa di antara sahabat Rasul ada yang berpendapat bahwa makmum yang masbuq jika mendapatkan ruku' bersama imam walaupun di luar shaf, maka dia mendapatkan raka'at tersebut. Adapun riwayat-riwayat yang dimaksud adalah sebagai berikut:

\section{Riwayat Ibnu Mas'ud}

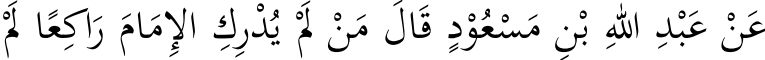

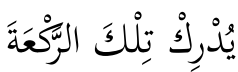

Dari Abdullah bin Mas'ud, ia berkata, "Siapa yang tidak dapat menyusul imam ketika ruku', ia tidak mendapatkan rakaat itu" H.R. Al-Baihaqi, as-Sunanul Kubra, II:90.

\footnotetext{
${ }^{26}$ A. Zakaria. Al-Hidayah. Hal. 142-145 dengan mengutip Kitab 'Aunul Ma'bud, jilid 3, 147.
}

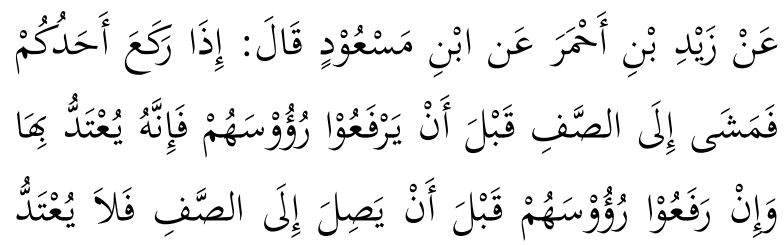

L.

Dari Zaid bin Ahmar, dari Ibnu Mas'ud, ia berkata, "Apabila seseorang di antara kamu ruku', lalu berjalan (sambil ruku') menuju shaf sebelum jama'ah mengangkat kepala mereka, maka ia mendapatkan raka'at itu. Dan jika mereka mengangkat kepala sebelum ia masuk ke shaf, maka raka'at itu jangan dihitung. "HR. At-Thabarani, al-Mu'jamul Kabir, IX:270

Kedua riwayat ini secara tegas menerangkan pendapat Ibnu Mas'ud bahwa jika makmum masbuq mendapatkan ruku' bersama imam walaupun di luar shaf, sebelum imam bangkit dari ruku'nya, dia mendapatkan raka'at tersebut. Pendapatnya ini secara konsisten diamalkan ketika beliau masbuq bersama Zaid bin Wahab, bahkan beliau mencegah Zaid bin Wahab ketika akan menambah raka'at yang terlewat. Hal itu sebagaimana diterangkan dalam riwayat sebagai berikut:

عَنْ زيَِّْ بْنِ وَهْبِ قَالَ خَرَجْتُ مَعَ عَبْدِ اللِهِ يَعْنِيْ بْنَ

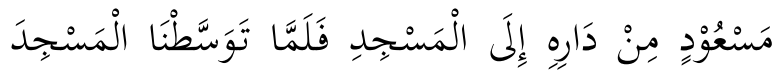

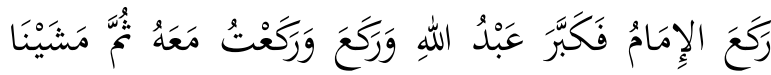

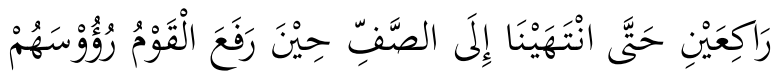

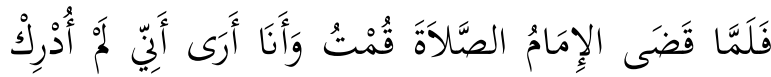

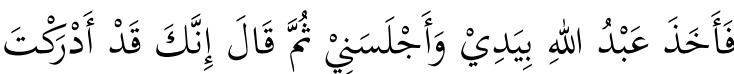

Dari Zaid bin Wahab, ia berkata, "Aku keluar bersama Abdullah bin Mas'ud dari rumahnya menuju ke masjid. Tatkala kami berada di tengah masjid itu, imam telah ruku, maka Ibnu Mas'ud bertakbir dan ruku dan aku pun ruku bersamanya, kemudian kami berjalan dalam keadaan ruku hingga sampai di shaf ketika jamaah mengangkat kepala mereka. Ketika imam selesai dari salatnya, aku berdiri dan aku berpendapat tidak mendapatkan rakaat itu. Lalu Ibnu Mas'ud memegang tanganku dan mendudukkanku, kemudian berkata, 
'Sesungguhnya kamu sudah mendapatkan rakaat'.” HR. Al-Baihaqi, as-Sunanul Kubra, II:90;At-Thabarani, al-Mu'jamul Kabir, IX:270. ${ }^{27}$

Selanjutnya pada riwayat at-Thabrani lainnya dengan redaksi:

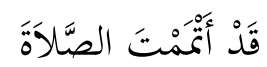

"Sungguh kamu telah menyempurnakan salat itu”

Demikian pula ketika beliau masbuq bersama kawan-kawannya (satu orang shahabat Rasul bernama Thariq bin Syihab dan sembilan orang tabi'in), sebagai berikut:

$$
\begin{aligned}
& \text { عَنْ طَرِقِ بْنِ شِهَابِ قَالَ كُنَّا عِنْدَ عَبْدِ اللَّهِ جُجُوسًا }
\end{aligned}
$$

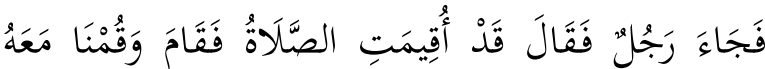

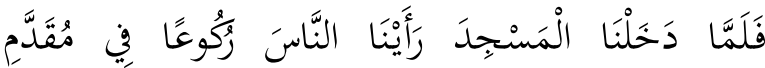

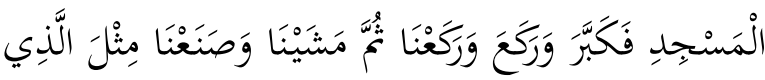

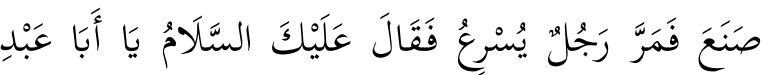

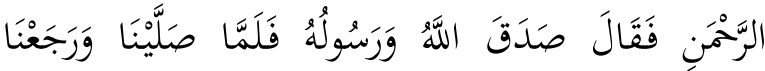

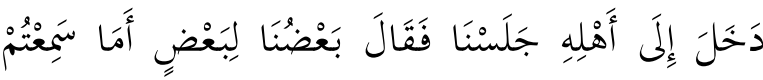

$$
\begin{aligned}
& \text { رَدَّهُ عَلَى الرَّجُلِ صَدَقَ اللَّهُ.... }
\end{aligned}
$$

Dari Thariq bin Syihab, ia berkata, "Kami sedang berkumpul di rumah Ibnu Mas'ud, Maka datang seseorang, lalu berkata, 'Iqamah telah dikumandangkan' Kemudian Ibnu Mas'ud berdiri dan kami pun berdiri bersamanya. Ketika kami masuk mesjid, kami lihat orang-orang sedang ruku di bagian depan masjid, maka Ibnu Mas'ud ruku dan kami pun ruku, lalu kami berjalan dan melalukan seperti yang dilakukannya (berjalan sambil ruku). Maka seseorang lewat dengan cepat, lalu berkata, "Alaikas salam wahai Abu Abdurrahman' Ibnu Mas'ud menjawab (waktu ruku), 'Shadaqallah wa rasuluhu'. Ketika kami selesai salat dan kembali (ke rumah Ibnu Mas'ud), ia menemui keluarganya, kami menunggu. Maka sebagian di antara kami bertanya, 'Apakah kalian mendengar jawaban (salam) beliau kepada orang itu 'Shadaqallah'." HR. Ahmad, Musnad al-

\footnotetext{
${ }^{27}$ Wawan, Shofwan, dkk. Makmum Masbuq Mendapat Ruku' Imam.
}

Imam Ahmad, VI:179, No. hadis 3.664;VI:415-416, No. hadis 3.870

Seandainya qaul dan amal ini benar-benar bersumber dari Ibnu Mas'ud, maka besar kemungkinan peristiwa itu terjadi setelah 10 hingga 12 tahun Rasul meninggal, yakni ketika Ibnu Mas'ud menetap di Kufah selama 3 tahun, sejak tahun $21 \mathrm{H} / 641 \mathrm{M}$ hingga $23 \mathrm{H} / 643 \mathrm{M}$ tatkala diutus oleh Umar bin Khatab sebagai mu'allim (pengajar) dan wazir (pengatur) baitul mal mendampingi Ammar bin Yasar sebagai 'Amir (Gubernur) di sana. Sepeninggal Umar (23 H/643 M), ia diangkat sebagai 'Amir oleh Usman, hanya tidak lama kemudian Usman memintanya untuk kembali ke Madinah. ${ }^{28}$

Namun ternyata, lanjut Dewan Hisbah, qaul dan amal ini disangsikan kebenarannya, karena menurut penelitian kami, riwayatriwayat tersebut tidak selamat dari ke-dha'ifan. Dengan argumentasi sebagai berikut:

\section{Ke-dha'if-an Riwayat Ibnu Mas'ud}

Riwayat- riwayat di atas menyatakan secara tegas bahwa:

- Ibnu Mas'ud ruku' di belakang shaf, lalu berjalan sambil ruku' menuju shaf. Hal itu dipertegas oleh Qatadah yang menyatakan:

$$
\text { أَنَّ ابْنَ مَسْعُوْدِ قَالَ لاَ بَأْسَ أَنْن تَرَكَعَ دُوْنَ الصَّفِّ }
$$

Sesungguhnya Ibnu Mas'ud berkata, "Tidak mengapa anda ruku (sendirian) di belakang shaf' HR. at-Thabrani, AlMu'jamul Kabir, IX:271, No. hadis 9.356)

Ibnu Mas'ud menetapkan ukuran makmum mendapatkan raka'at itu adalah $r u k u$ 'nya imam.

Selain meneliti syarh dari hadis-hadis tersebut,kemudian Dewan Hisbah mentakhrij susunan sanad-nya, ternyata pada riwayatriwayat tersebut terdapat beberapa ke-dha'ifan, yaitu:

\section{Riwayat Qauli}

a. Pada riwayat al-Baihaqi terdapat dua kedha'if-an, yakni (1) pada sanad itu disebutkan bahwa Ali bin Ashim berkata, "Telah menceritakan kepada kami Khalid

\footnotetext{
${ }^{28}$ Lihat, al-Ishabah fi Tamyizis Shahabah, jilid II,
} 37. 
al-Hadzdza (ia menerima), dari Ali bin alAqmar, dari Abul Ahwash." Menurut penelitian kami sanad ini munqathi' (terputus), karena Khalid al-Hadzdza tercatat mempunyai 40 orang guru, namun tidak ada satu pun yang bernama Ali bin al-Aqmar (lihat, Tahdzibul Kamal, VIII:178-179). Demikian pula halnya dengan Ali bin al-Aqmar tercatat mempunyai 17 orang murid, namun tidak ada satu pun yang bernama Khalid alHadzdza (lihat, Tahdzibul Kamal, XX:324). (2) pada sanad itu terdapat rawi bernama Ali bin 'Ashim bin Shuhaib. Kata Yazid bin Zurai', "Ali telah menceritakan kepada kami dari Khalid sebanyak 10 hadis lebih, lalu kami menanyakan hadis itu kepada Khalid satu demi satu' Maka Khalid berkata, "Dia pendusta, hati-hatilah terhadapnya'." (Lihat, At-Tarikhul Kabir, VI:290) Sehubungan dengan itu Ibnu Hajar berkata, "Shaduqun yukhtiu (dia keliru)" Lihat, Taqribut Tahdzib, I:403.

b. Pada riwayat at-Thabrani terdapat kedha'if-an, yakni pada sanad itu disebutkan bahwa Abdullah bin Yazid an-Nakha'i menerima dari Zaid bin Ahmar, dari Ibnu Mas'ud. Menurut penelitian kami sanad ini munqathi (terputus), karena anNakha'i tercatat mempunyai 4 orang guru, namun tidak ada satu pun yang bernama Zaid bin Ahmar. Di samping itu, rawi dengan nama Zaid bin Ahmar tidak tercatat pada kitab-kitab rijal. Namun yang tercatat bernama Yazid bin al-Ahmar (lihat, Tahdzibul Kamal, XVI:310). Seandainya yang dimaksud dengan Zaid bin Ahmar itu adalah Yazid, tetap saja hadis itu munqathi', karena ia tidak pernah menerima hadis dari Ibnu Mas'ud. Bahkan ia hanya menerima hadis dari Hudzaifah bin al-Yaman. (Lihat, AtsTsiqat, V:535).

c. Pada riwayat at-Thabarni dari Qatadah, dari Ibnu Mas'ud terjadi inqitha (terputus) sanadnya, yakni ghair mu'asharah (tidak sezaman) antara Qatadah bin Di'amah dengan Ibnu Mas'ud, sebab Ibnu Mas'ud wafat tahun $32 \mathrm{H} / 652 \quad \mathrm{M}$ (Lihat, Tadzkirratul Huffazh, juz I, hal. 14), sedangkan Qatadah bin Di'amah lahir 30 tahun setelah Ibnu Mas'ud wafat, yakni tahun 61 H/680 M. (Lihat, Tahdzibul Kamal, XXIII:517

\section{Riwayat Amali}

\section{Melalui Zaid bin Wahab.}

a. Kejadian Ibnu Mas'ud masbuq beserta Zaid diriwayatkan oleh at-Thabrani melalui beberapa jalur periwayatan, namun semuanya tidak terlepas dari kedaifan, yaitu (1) Dari Muhamad bin anNadhr al-Azdi, dari Mu'awiyah bin Amr, dari Zaidah bin Qudamah, dari Manshur. Dalam sanad lain, Zaidah, dari Mughirah, dari Ibrahim an-Nakha'i tanpa menyebut nama orang yang masbuk bersama Ibnu Mas'ud itu, tetapi hanya disebut shahib Abdullah (kawan Ibnu Mas'ud). Menurut penelitian kami sanad ini tidak pasti muttasil- (bersambung) nya, karena di dalam kitab-kitab rijal ada tiga rawi bernama Muhamad bin an-Nadhr; (a) bin Salamah al-'Amiri al-Jarudi, (b) bin Abdul Wahhab an-Naisaburi, (c) bin Musawir al-Marwuzi, namun tidak ada satu pun yang disebut al-Azdi. Di samping itu, ketiganya tidak tercatat sebagai guru at-Thabrani. (Lihat, Tahdzibul Kamal, XXVI:553-556, No. rawi 5.656, 5.5657, 5.658); (2) Dari Ishaq bin Ibrahim, dari Abdur Razaq, dari Sufyan at-Tsauri, dari Manshur. Menurut penelitian kami di dalam kitab-kitab rijal terdapat 15 orang bernama Ishaq bin Ibrahim, namun yang tercatat sebagai periwayat dari Abdur Razaq hanya 3 orang, yaitu (a) bin Rahawaih, (b) bin Nashr, (c) bin Abbad ad-Dabari (Lihat, Tahdzibul Kamal, II:361-396; XVIII:54; al-Kamil fi Dhu'afair Rijal, I:344). Pada sanad ini tidak dijelaskan Ishaq yang dimaksud. Tetapi bila digunakan dalam periwayatan at-Thabrani, maka yang termasyhur adalah Ishaq bin Ibrahim bin Abbad adDabari. Sedangkan periwayatan Ishaq adDabari dari Abdur Razaq terdapat masalah, yakni (1) ia tidak pernah menerima hadis secara langsung dari Abdur Razaq, tetapi melalui ayahnya Ibrahim (lihat, Lisanul Mizan, I:349). (2) 
Ia menerima beberapa hadis secara langsung dari Abdurrazaq, namun Abdur Razaq telah ikhtilath (buta matanya). Karena itu, Imam Ahmad berkata, "Siapa yang menerima hadis dari Abdur Razaq setelah buta matanya, maka penerimaan itu dha'if' (Lihat, Tahdzibul Kamal, XVIII:58). Menurut Ibnu Hajar, "Hadishadis Ishaq ad-Dabari dari Abdur Razaq yang tidak dimuat pada kitab-kitabnya, maka hadisnya munkar, karena ia menerima darinya setelah ikhtilath" (Lihat, Lisanul Mizan, I:350). Karena hadis ini tidak dimuat pada kitab Abdur Razaq, maka hadis ini munkar (tertolak), yakni diriwayatkan olehnya setelah Abdur Razaq ikhtilath. (3) Dari Ali bin Abdul Aziz, dari Hajjaj bin Minhal, dari Abu 'Awanah, dari Manshur. Menurut penelitian kami sanad ini tidak pasti muttasil-nya, karena Abu 'Awanah tidak menyebutkan secara pasti bentuk penerimaan hadis itu dari Manshur, ia hanya menyebut 'an (dari). Sedangkan menurut para ahli hadis periwayatan Abu 'Awanah dapat ditetapkan muttashil (bersambung) bila ia meriwayatkan dari catatannya, namun jika melalui hapalannya, maka hadis itu tidak selamat dari kesalahan. (lihat, Tahdzibul Kamal, XXX:447).

b. Riwayat al-Baihaqi diterima dari Abu Nashr bin Qatadah, dari Abul Fadhl bin Humairuwaih, dari Ahmad bin Najdah, dari Sa'id bin Manshur, dari Abul Ahwash, dari Manshur. Menurut penelitian kami sanad ini munqathi' (terputus), karena Ahmad bin Najdah tidak menerima hadis ini dari Sa'id bin Manshur. Dan ia hanya sebagai periwayat kitab as-Sunan dari Sa'id bin Manshur, bukan sebagai periwayat hadisnya. Sedangkan hadis ini tidak tercatat dalam kitab Sunan tersebut. (lihat, Tahdzibul Kamal, XI:79).

c. Hadis tersebut diriwayatkan pula oleh Ibnu Abu Syaibah, dari Abul Ahwash Salam bin Sulaim, dari Manshur, dari Zaid bin Wahab (Lihat, al-Mushannaf, I:229). Menurut penelitian kami hanya riwayat inilah yang dapat dipastikan muttashil.

\section{Melalui Thariq bin Syihab.}

Kejadian Ibnu Mas'ud masbuq beserta kawan-kawannya diriwayatkan oleh Imam Ahmad melalui dua jalur periwayatan; (a) Thariq bin Syihab, (b) al-Aswad bin Zaid. Namun kedua sanad itu tidak terlepas dari ke-dha'if-an, yaitu (1) pada sanad Thariq terdapat rawi bernama Sayyar. Para ahli hadis bersilang pendapat tentang Sayyar yang dimaksud pada sanad ini, antara Abul Hakam atau Abu Hamzah. Basyir bin Sulaiman, Makhlad bin Yazid, Waki', Yahya bin Adam, Abdullah bin Daud, Abu Ahmad az-Zubairi (para periwayat hadis itu dari Sayyar), semuanya mengatakan, "Dari Sayyar Abul Hakam" (Lihat, 'Ilal ad-Daraquthni, V:115). Namun Ahmad, Abu Daud, Yahya bin Ma'in, dan ad-Daraquthni menyatakan bahwa dia Yahya Abu Hamzah. Menurut mereka, "Sungguh keliru yang mengatakan bahwa dia Sayyar Abul Hakam". (Lihat, Dr. Syu'aib al-Arnauth, dkk. pada Ta'liq 'ala Musnad al-Imam Ahmad, VI:416). Dengan demikian, selama tidak dapat ditetapkan kebenaran di antara nama itu, maka sanad tersebut dapat dikategorikan idhtirrab (kacau); (2) pada sanad al-Aswad bin Zaid terdapat rawi bernama Mujalid bin Sa'id bin Umair. Imam Ahmad, sebagai periwayat hadis itu menyatakan, "Laisa bisyain (sama sekali tidak bernilai/berkualitas)" (lihat, Tahdzibul Kamal, XXVII:221). Ibnu Hajar berkata, "Laisa bil Qawwi (tidak kuat), benar-benar pikun di akhir hayatnya" (Lihat, Taqribut Tahdzib, I:520)

Setelah karena sebabke-dha'if-an di atas maka tidak benar kalau riwayat itu dinyatakan sebagai amal dan pendapat Ibnu Mas'ud. ${ }^{29}$

\section{Ke-dha'if-an Riwayat Ibnu Mas'ud Versi Ibnu Abu Syaibah}

Kejadian Ibnu Mas'ud masbuq beserta Zaid diriwayatkan pula oleh Ibnu Abu Syaibah, dari Abul Ahwash Salam bin Sulaim, dari Manshur, dari Zaid bin Wahab

\footnotetext{
${ }^{29}$ Wawan, Shofwan, dkk. Makmum Masbuq Mendapat Ruku' Imam. tim sekretariat dewan hisbah persatuan islam. Bandung. 2006.
} 
(Lihat, al-Mushannaf, I:229). Riwayat ini mukhalafah (menyalahi/bertentangan) dengan beberapa riwayat shahih tentang aturan salat berjama'ah yang ditetapkan Rasulullah, sebagai berikut:

Pada riwayat tersebut diterangkan bahwa Ibnu Mas'ud dan Zaid ruku di luar shaf. Padahal Rasul melarangnya. Hal ini sebagaimana diterangkan oleh Abu Hurairah

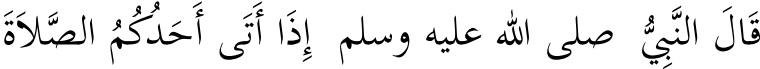

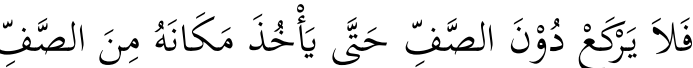

Nabi saw. bersabda, "Apabila seseorang di antara kamu mendatangi salat (berjama'ah), maka jangan ruku di luar shaf, hingga menempati tempatnya pada shaf itu. ${ }^{30}$ HR. At-Thahawi, Syarh Ma'anil Atsar, I:396.

Pada riwayat tersebut diterangkan bahwa Ibnu Mas'ud dan Zaid ruku sambil berjalan menuju shaf. Padahal amal seperti ini jelas dilarang oleh Rasul berdasarkan hadis Abu Bakrah sebagai berikut:

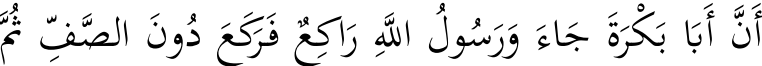

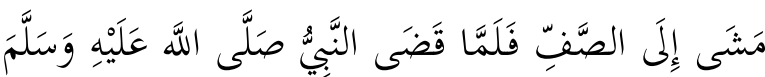

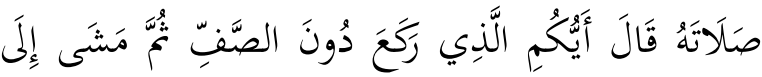

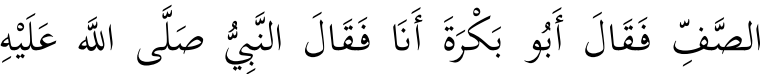

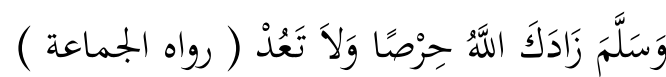

"Sesungguhnya Abu Bakrah datang ketika Rasul sedang ruku, lalu ia ruku di luar shaf kemudian berjalan (dalam keadaan ruku) menuju shaf. Ketika Nabi selesai salatnya, beliau bersabda, 'Siapa di antara kalian yang ruku di luar shaf kemudian berjalan (dalam keadaan ruku) menuju shaf?' Maka Abu Bakrah berkata, "Saya". Kemudian Nabi bersabda, "Semoga Allah menambah semangatmu, dan janganlah kamu mengulangi (amal seperti itu)" HR. AlJama'ah, dan redaksi ini riwayat Abu Daud. ${ }^{31}$

\footnotetext{
${ }^{30}$ Wawan, Shofwan, dkk. Makmum Masbuq Mendapat Ruku' Imam. tim sekretariat dewan hisbah persatuan islam. bandung. 2006

${ }^{31} \mathrm{Abu}$ al-Fadl Ahmad bin 'Ali bin Hajr al-'Asqalani, Fath al-Bari Syarh Sahallahh al-Bukhari. Juz I. (Beirut: Darr al-Ma'rifah, 1379 H), 270.
}

Demikian pula dengan keumuman perintah yang senantiasa dikemukakan oleh Nabi kepada orang (makmum) yang masbuq, sebagai berikut:

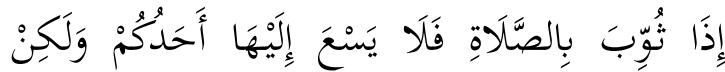

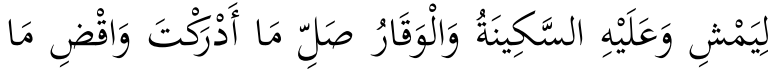
سَبَقَكَكَ

"Apabila salat telah dilaksanakan, janganlah seseorang berjalan dengan tergesa-gesa mendatangi salat itu, tetapi hendaklah ia tenang. Lakukanlah apa yang kamu dapati dan sempurnakanlah apa yang terlewat". H.r. Muslim, dan pada riwayat AlBukhari dengan redaksi:

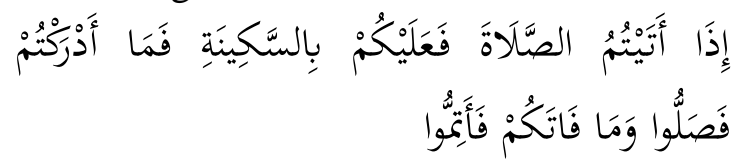

"Apabila kalian mendatangi salat, hendaklah tenang. Apa yang dapat kalian susul maka lakukanlah dan apa yang tertinggal maka sempurnakanlah".

Pada riwayat tersebut diterangkan bahwa Ibnu Mas'ud menetapkan ukuran makmum mendapatkan raka'at itu adalah rukunya imam. Padahal Nabi menyuruh Abu Bakrah yang dapat menyusul ruku imam untuk menambah rakaat yang terlewat itu dengan kalimat

$$
\text { صَلِّ مَا أَدْرَكْتَ وَاقْضِ مَا سَبَقَكَكَ }
$$

"Lakukanlah apa yang kamu dapati dan sempurnakanlah apa yang terlewat” H.r. AlBukhari dalam al-Qiraah Khalfal Imam.

Perintah Nabi kepada Abu Bakrah ini menunjukkan bahwa yang menjadi tolok ukur makmum mendapatkan satu rakaat bukan ruku'nya imam. Hal ini dipertegas pula oleh Abu Hurairah

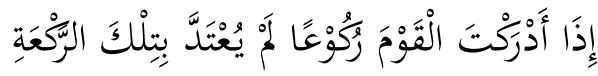

“Apabila kamu menyusul jama'ah salat sedang ruku, maka rakaat itu jangan dihitung" (Lihat, Talkhishul Habir, II:545, No. 595).

Pernyataan Abu Hurairah tersebut semakin mempertegas sikap para sahabat terhadap masalah makmum masbuk mendapati imam sedang ruku' tidak dihitung satu raka'at. 
Dengan ketiga faktor mukhalafah di atas tampak jelas ke-dha'if-an riwayat Ibnu Abu Syaibah yang disandarkan kepada Ibnu Mas'ud tersebut, karena tidak mungkin sahabat menyalahi sunnah Rasul. ${ }^{32}$

\section{Riwayat Ibnu Umar}

$$
\begin{aligned}
& \text { عَنِ ابْنِ عُمَرَ قَالَ إِذَا أَدْرَكْتَ الإِمَامَ رَاكِعًا فَرَكْعْتَ قَبْلَ }
\end{aligned}
$$

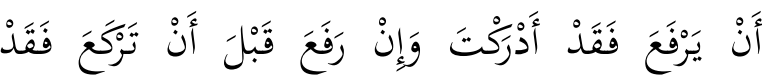

$$
\begin{aligned}
& \text { فَاتَتْكَ. ت رواه عبد الرزاق }
\end{aligned}
$$

Dari Ibnu Umar, ia berkata, "Apabila kamu dapat menyusul imam sedang ruku, lalu kamu ruku' sebelum ia (imam) bangkit, maka kamu telah mendapatkan (raka'at). Dan jika ia bangkit sebelum kamu ruku, maka kamu terlewat (rakaat) itu."HR. Abdur Razaq, al-Mushannaf, II:279. Dalam riwayat al-Baihaqi dengan redaksi:

$$
\begin{aligned}
& \text { مَنْ أَدْرَكَ الإِمَامُ رَاكِعَا فَرَكَعَ قَبْلَ أَنْ يَرْفَعَ الإِمَامُ رَأْسَهُ }
\end{aligned}
$$

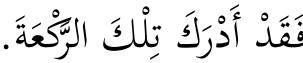

"Siapa yang dapat menyusul imam sedang ruku', lalu kamu ruku sebelum imam bangkit, maka kamu telah mendapatkan raka'at itu" As-Sunanul Kubra, II:90. Sedangkan dalam riwayat Ibnu Abu Syaibah dengan redaksi:

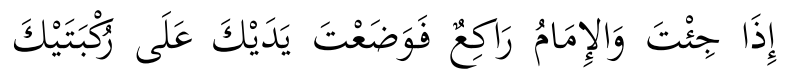

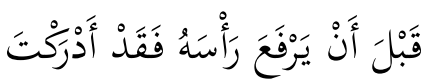

"Apabila kamu datang ketika imam sedang ruku, lalu kamu ruku sebelum imam bangkit, maka kamu telah mendapatkan (rakaat itu)" Al-Mushannaf, I:219

Ketiga riwayat ini secara tegas menerangkan pendapat Ibnu Umar bahwa jika makmum masbuq mendapatkan ruku' bersama imam berarti dia mendapatkan raka'at tersebut. Namun setelah diteliti oleh Dewan Hisbah, ternyata pada ketiga riwayat tersebut terdapat beberapa ke-dha'if-an, yaitu:

\footnotetext{
${ }^{32}$ Wawan Shofwan. Masbuq Mendapatkan Ruku' Imam. Tim sekretariat Dewan Hisbah Persatuan Islam. Bandung. 2006.
}

\section{Riwayat Abdurrazaq dan Ibnu Abu Syaibah.}

Kedua riwayat ini diterima melalui Ibnu Juraij, dari Nafi dengan menggunakan dua bentuk periwayatan. Pada riwayat Ibnu Abu Syaibah menggunakan lafal عن (dari), sedangkan pada riwayat Abdurrazaq menggunakan kalimat قَالَ أَحْبركنِ Kedua bentuk periwayatan tersebut menunjukkan bahwa pada sanad ini terjadi tadlis isnad (penyamaran sanad), yakni ketidakpastian Ibnu Juraij dalam menerima riwayat tersebut dari Nafi', karena Ibnu Juraij dikenal mudallis isnad (menyamarkan sanad karena ragu-ragu), sebagaimana dinyatakan oleh

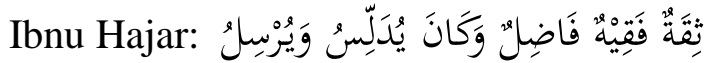

"Dia tsiqat (terpercaya), ahli fiqih, terkemuka, dan ia melakukan tadlis dan irsal (meriwayatkan hadis Nabi tanpa menyebut sahabat)" Taqribut Tahdzib, I:363

Sehubungan dengan itu Imam Ahmad berkata:

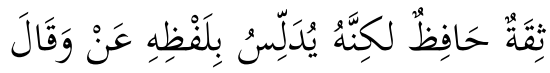

"Dia tsiqat, hafizh, tetapi melakukan tadlis dengan lafal 'an danqala". Siyaru A'lamin Nubala, VI:332.

Dengan demikian hadis ini dha'if, karena rawinya seorang mudallis isnad.

\section{Riwayat Al-Baihaqi}

Riwayat ini dha'ifkarena pada sanad-nya terdapat rawi bernama al-Walid bin Muslim. Abu Hatim mengatakan, 'Sering waham (ragu-ragu dalam periwayatan)'Dan pada riwayat lainnya beliau berkata, 'Sering keliru". Tahqiq 'ala Tahdzibil Kamal, XXXI:94. Sehubungan dengan ke-dha'if-an riwayat Ibnu Mas'ud dan Ibnu Umar di atas, maka kami tetap berpegang pada kesimpulan semula bahwa yang menjadi tolok ukur makmum mendapatkan satu raka'at bukan rukunya imam, melainkan bacaan surat alFatihah.

Demikian tanggapan dari Dewan Hisbah tentang hadis yang dijadikan argumentasi kelompok pertama.Sedangkan tanggapan untuk hadisyang dijadikan argumentasi kelompok kedua, adalah: 


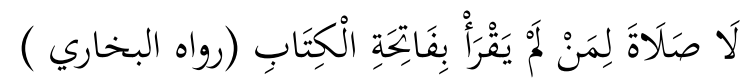

"Tidak ada salat bagi yang tidak membaca al-Fatihah." HR.. Al-Bukhari

Kalimat laa shalata (tidak ada salat) merupakan bentuk nafi (peniadaan) namun bermaknanahyi (larangan). Jadi hadis itu mengandung pengertian "jangan shalat tanpa membaca Al-Fatihah". Pengertian ini mengacu pada riwayat Ibnu Khuzaimah, Ibnu

Hiban, dan mukharij lainnya dengan lafal:

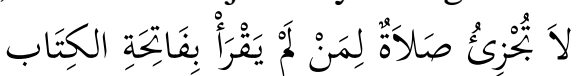

Tidaklah cukup salat bagi yang tidak membaca Al-Fatihah.Bahkan di dalam riwayat Ahmad dengan kalimat yang lebih tegas:

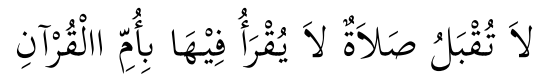

Tidak diterima salat apapun yang padanya tidak dibaca al-Fatihah.

Dengan keterangan-keterangan ini jelaslah bahwa makna tidak ada shalat bagi yang tidak membaca al-Fatihah adalah tidak sah setiap raka'at tanpa al-Fatihah. Dan hadis ini bersifat 'am, yakni meliputi shalat munfarid dan berjamaah, serta berlaku untuk imam maupun makmum. Karena itu, apabila makmum ber-takbiratul ihram tidak dari awal Fatihah pada satu raka'at, maka ia tidak mendapatkan raka'at itu.

Setelah mempelajari argumentasi dari kedua belah pihak, kami (Dewan Hisbah) cenderung kepada pendapat kelompok kedua bahwa apabila seorang makmum yang menyusul imam dalam posisi apa pun dan ia tertinggal al-Fatihah sejak awal, maka wajib mengulangi raka'at yang tertinggal itu, dan baru dihitung satu raka'at jika makmum sempat membaca atau mendengarkan alFatihah dengan sempurna, mengingat:

1. Membaca atau mendengarkan al-Fatihah itu wajib dalam setiap raka'at. Berarti tidak membaca atau tidak mendengarkannya, tidak terhitung satu raka'at.

2. Terdapat perintah kepada ma'mum untuk menyempurnakan yang ketinggalan. Berarti ketinggalan al-Fatihah hendaklah disempurnakan.

3. Imam Bukhori sendiri sebagai orang yang terkenal ahli hadis berpendapat bahwa ma'mum yang hanya mendapatkan ruku' saja, ia dianggap tidak mendapatkan raka'at sampai ia sempat membaca alFatihah.

4. Hadis-hadis yang menyatakan asal keburu ruku' dihitung satu raka'at, tidak ada yang kuat (dla' $\hat{\imath} f){ }^{33}$

Dengan demikian, dari analisis penulis di atas, penulis berkesimpulan bahwa Dewan Hisbah tidak menggunakan hadis yang dipakai oleh kelompok pertama sebagai dalil untuk ketentuan orang yang masbuq mendapatkan ruku' imam, dapat dihitung raka'atnya dan tidak perlu ditambah lagi raka'atnya, karena derajat hadis-hadis tersebut dla' $\mathrm{\imath} f$ dari segi sanad dan matan, dari segi sanad yaitu dengan adanya rawi yang derajatnya munkar, pendusta, dan sanadnya munqathi'. Pada hadis riwayat Abu Daud 'jika makmum mendapatkan ruku' imam, termasuk satu raka'at", hadisnya tidak ditemukan dalam riwayat Abu Daud, namun di temukannya di dalam riwayat Daruquthny, serta tidak ada muttabi' yang menguatkan hadis tersebut, dan terdapat tambahan kalimat pada matan-nya(mudraj fil matan), dan pada riwayat Ibnu Mas'ud, terdapat rawi yang telah iktilath (buta matanya), Selain itu terdapat pula seorang rawi yang mudallis isnad, hadisnya pun mursal dengan tidak disertai qarinah yang menunjukkan ittishalnya hadis tersebut. Sebagaimana diterangkan dalam metode Istidlâl bil-Hadis-nya bahwa Dewan Hisbah tidak menerima hadis dla'îfdengan sebab ada kecacatan dari segi 'adalah (keadilan seorang rawi) seperti pendusta (kadzdzab) dimana syarat tersebut merupakan syarat yang utama yang harus dihindari, yang dihindari pula oleh ahli hadis, dan tidak menerima hadis yang rawinya melakukan tadlis, kecuali jika menerangkan bahwa apa yang ia riwayatkan itu jelas Shigat Tahammul-nya (kata yang digunakan dalam menerima hadis dari guru) menunjukkan ittishal-nya hadis tersebut, seperti menggunakan kata "haddatsni"

\footnotetext{
${ }^{33}$ A. Zakaria. Al-Hidayah. 146.
} 


\section{Analisis Terhadap Hasil Fatwa Dewan Hisbah Melalui Metode Takhrij}

Atas apa yang telah dilakukan oleh Dewan Hisbah, penulis dapat memberikan analisa ringkas sebagai berikut:

a. Hadis-hadis yang dijadikan argumentasi kelompok pertama:

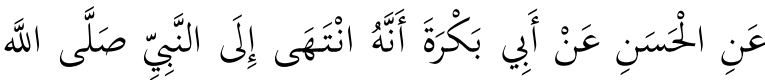

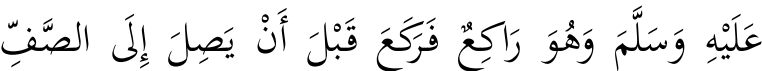

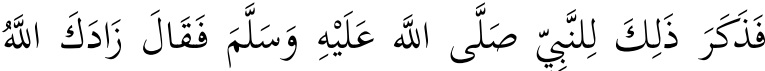

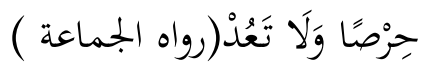

Dari al-Hasan, dari Abu Bakrah, sesungguhnya ia sampai kepada Nabi saw. ketika sedang ruku', lalu ia ruku' sebelum sampai ke shaf, kemudian ia menceritakan hal itu kepada Nabi saw. Maka beliau bersabda, "Semoga Allah menambahkan semangat terhadapmu dan janganlah engkau ulangi"'.( HR. Al-Jama'ah)

عَنْ أَبِي هُرَيْرَة قَالَ قَالَ رَسُولُ اللَّهِ صَلَّى اللَّه عَلَيْْهِ وَسَلَّمَ

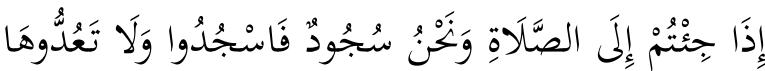

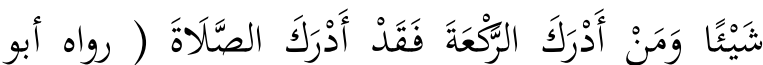

( 2 (a

Dari Abu Hurairah, ia berkata, "Rasulullah saw. bersabda, 'Jika kamu mendatangi shalat, padahal kami sedang sujud, maka sujudlah dan janganlah kamu menghitungnya satu raka'at (mendapatkan raka'at). Dan barangsiapa mendapatkan raka'at (ruku'), maka dia mendapatkan shalat'." HR. Abu Daud. Sunan Abi Daud, 1: 207

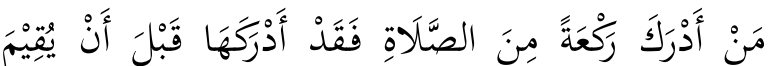
الإِمَامُ صُلْبَهُ عَنْ أَبْي هُرَيْرَةَ قَالَ قَالَ رَسُولُ اللَّهِ صَلَّى اللَّه<smiles>[Al][As]</smiles>

Dari Abu Hurairah, Rasulullah berkata, "Barangsiapa menyusul satu raka'at dari shalat maka ia telah menyusul raka'at itu sebelum imam meluruskan punggungnya." b. Hadis yang dijadikan argumentasi kelompok kedua

$$
\begin{aligned}
& \text { عَنْ عُبَادَة بْنْ الصَّامِتِ: أَنَّ رَسُولَ اللَّهِ صَلَّلَى اللهُ عَلَيْهِ }
\end{aligned}
$$

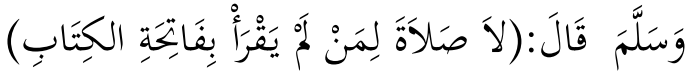

Dari 'Ubadah bin Ash Shamit, bahwa Rasulullah shallallahu 'alaihi wasallam bersabda: "Tidak ada shalat bagi yang tidak membaca Faatihatul Kitab (Al Fatihah)." HR. Al-Jama'ah

$$
\begin{aligned}
& \text { إِذَا ثُوِّبَ بِالصَّلَاةِ فَلَا يَسْعَ إلَِيْهَا أَحَدُكُمْ وَلَكِنْ }
\end{aligned}
$$

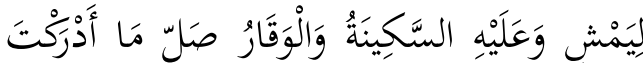

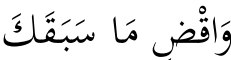

"Apabila shalat telah dilaksanakan, janganlah seseorang berjalan dengan tergesa-gesa mendatangi shalat itu, tetapi hendaklah ia tenang. Lakukanlah apa yang kamu dapati dan sempurnakanlah apa yang terlewat”. (H.R. Muslim).

Pada hadis-hadis riwayat di atas, semua hadis terdapat rawi yang bernama Yahya bin Abi Sulaiman beliau banyak yang menilai seorang yang lemah (dha'if), dan Munkar Hadis, dalam kitab Ma'rifat as-Sunan wal Atsar beliau seorang yang menyendiri, tidak ada yang men-jarh, kata Abu Hatim al-Razi Majhul, Mudtharib Hadis. Bahkan dalam riwayat Bayhaqi ada seseorang yang tidak disebutkan identitasnya (Mubham). Jiak dilihat dari ketersambungannya antara satu rawi dengan rawi yang lain muttashil, akan tetapi hadisnya menjadi dha'if , namun AlAlbani menghasankan hadis-hadis tersebut di atas.

\section{SIMPULAN}

Setelah melakukan analisis seperti di uraikan pada bab sebelumnya, maka penulis dapat menarik kesimpulan terhadap Metode Dewan Hisbah Persis dalam Ber-Istidlal dengan Hadis Studi terhadap Fatwa Dewan Hisbah tentang Makmum yang Masbuq sebagai berikut.

1. Dewan Hisbah dalam sejarahnya merupakan cikal bakal berdirinya Persatuan Islam (Persis) karena jauh sebelum lahir Persis telah ada kelompok 
penela'ah seputar agama Islam, dari sanalah cikal bakal Dewan Hisbah muncul, berbarengan dengan berdirinya Persis sebagai Organisasi Masyarakat yang bergerak di bidangdakwah. Dan lahirlah secara resmi Dewan Hisbah yang asalnya bernama Majelis Ulama, karena tugas dari Majelis Ulama (DewanHisbah) adalah melakukan pengkajian fatwa dalam jam'iyyah, serta memutuskan persoalanpersoalan yang berkembang.

2. Pandangan Dewan Hisbah persis terhadap hadis, adalah bahwa Al-Sunnah dapat dijadikan hujjah dalam menentukan hukum, Sunnah dapat berfungsi seperti Al-Quran dalam menentukan hukum halal dan haram, wajib atau sunah, selama tidak bertentangan dengan Al-Quran dan hadishadis yang lebih shahih.

3. Metode Dewan Hisbah persis dalam beristidlal dengan hadis, bahwa Dewan Hisbah menentukkan metode(manhaj) dalam memutuskan atau mengambil keputusan hukum, dengan rumusanrumusan sebagai berikut: Dasar utama adalah al-Quran dan hadis shahih: a) Di dalam ber-istidlal dengan al-Quran b) Ber-istidlal dengan Hadis c) Dalam masalah-masalah yang tidak diketemukan nash-nya yang shahih dalam al-Quran dan Hadis, ditempuh dengan ijtihad jama'i.

4. Aplikasi dalam ber-Istidlal dengan hadis tentang makmum yang masbuq menambah raka'at, dengan merujuk hadishadis yang menjelaskan tentang makmum masbuq mendapat ruku' imam. Bahwa dalam hal ini, Dewan Hisbah tidak menerima hadis, kalau makmum masbuq mendapat ruku' imam di hitung raka'at, karena hadisnya dha'if, dengan beberapa faktor, diantaranya rawi yang munkar, kadzdzab, mudallisisnad, sanad yang terputus (mursal), matan-nya yang terjadi mudraj (kacau). Dan perintah Nabi kepada Abu Bakrah menunjukan bahwa

a. Makmum yang masbuq mendapatkan imam (Nabi saw), sedang ruku', lalu dia ruku bersama imam, maka dipandang ketinggalan raka'at. b. Yang menjadi tolak ukur makmum mendapatkan satu raka'at bukan ruku'nya imam.

Apabila seorang makmum yang menyusul imam dalam posisi apa pun dan ia tertinggal al-Fatihah sejak awal, maka wajib mengulangi raka'at yang tertinggal itu, dan baru dihitung satu raka'at jika makmum sempat membaca atau mendengarkan alFatihah dengan sempurna.

\section{DAFTAR PUSTAKA}

'Itr, Nuruddin. Manhaj An-Naqd Fii 'Uluum Al-Hadits. terjemah Mujiyo. Bandung: PT. Remaja Rosdakarya, 2012.

Abbas, Rafid. Ijtihad Persatuan Islam. Tela'ah atas Produk Ijtihad PERSIS tahun 1996-2009. Yogyakarta: Pustaka Pelajar, 2013.

'Asqalani, Abu al-Fadl Ahmad bin 'Ali bin Hajr al-. Fath al-Bari Syarh Sahallahh alBukhari. Juz II. Beirut: Dar al-Ma'rifah, $1379 \mathrm{H}$.

Abdurrahman. Perbandingan Madzhab. Bandung: CV. Sinar Baru, 1991.

Amien, Shiddiq. Panduan Hidup Berjama'ah dalam Jam'iyyah Persis. Persis Pers. Bandung, 2007.

Amin, Phil. H. Kamaruddin. Metode Kritik Hadits. Jakarta: Hikmah, 2009.

Aplikasi Lidwa-i-Software-Kitab 9 Imam, Maktabah Syameelah, dan Jawami' AlKalim.

Ariyani, Wiwik. Skripsi Konsep Jihad dalam Menyikapi Kebijakan Politik luar Negeri Amerika Serikat terhadap Islam ( Studi Kasus Pandangan Persis jl. Viaduct ). 2009

Asmawi. Perbandingan Ushul Fiqh. Jakarta: Amzah. 2011.

Bachtiar, Tiar Anwar. Sejarah Pesantren Persis 1936-1983. Jakarta: Pembela Islam Media. 2012.

Dani Hidayat. Persatuan Islam Offline Versi 2.0. Pustaka Hidayah. t.t.

Darmalaksana, Wahyudin. Hadits dimata Orientalis. Telaah atas Pandangan Ignaz Goldziher dan Joseph Schacht. Bandung: Benang Merah Press. 2004

Fatarib, Husnul. Istidlal dalam Fikih dan Ushul Fikih (Kajian Terhadap Metode 
Legitimasi Hukum dalam Fikih Islam). Lampung: STAIN Jurai Siwo Metro. 2014.

http//.natsirritsfirdaus.blogspot.com diakses pada tanggal 12-12-2014 pkl. 11.10. Penerapan Hadits Ahkam Dewan Hisbah Persis.

Idri. Studi Hadits. Jakarta: Kencana Prenada Media Group. 2013.

Ismail, Syuhudi. Hadis Nabi yang Tekstual dan Kontekstual. Bulan Bintang. Jakarta 1994

Izzan, Ahmad dan Saifudin Nur. Ulumul Hadits. Bandung: Tafakur. 2011.

Jumantoro, Totok dan Samsul Munir Amin. Kamus Ilmu Ushul Fikih. Amzah. Jakarta. 2009

Kamiluddin, Uyun. Menyoroti Ijtihad Persis. Fungsi dan Peranannya dalam Pembinaan Hukum Islam di Indonesia. Bandung: Tafakur. 2006.

Khaeruman, Badri. Persatuan Islam. Sejarah Pembaruan Pemikiran "Kembali kepada Al-Quran dan Al-Sunnah". FAPPI dan IRIS Press. Bandung. 2010

Khaeruman, Badri. Ulum Al-Hadis. Bandung: Pustaka Setia, 2010.

Khalaf, Abdul Wahab. Ilmu Ushul Fikih. Jakarta: Pt. Rineka Cipta, 2005.

Khalaf, Syeikh Abdul Wahab.Ilmu Ushul Fikih. Jakarta: PT Rineka Cipta, 1995.

M. Abdurrahman dan Elan Sumarna. Metode Kritik Hadits. Bandung : Rosda Karya, 2011.

Mughal, Munir Ahmad. What Is Istidlal. Lahore: Punjab University Law College, 2012

Mughits, Abdul. Kritik Nalar Fiqih Pesantren. Jakarta: Kencana Prenada Media Group, 2008.

Mujiyo, Dkk. Buku Daras Ilmu Syarah Hadits (Sari Kuliah). Fakultas Ushuluddin IAIN Sunan Gunung Djati Bandung. 2005

Mukhtar, Amien. Syarh Makmum Masbuq Mendapat Ruku Imam. t.t.

Nazir, Moh. Metode Penelitian. Bogor: Ghalia Indonesia, 2011.

Nur, Saifudin. Ilmu Fiqh. Suatu Pengantar Komprehensif kepada Hukum Islam. Bandung:Tafakur, 2007.
Pedoman Penulisan Skripsi Fakultas Ushuluddin UIN SGD Bandung. 2012

Persatuan Islam. $Q A-Q D$ Penjelasan $Q A-Q D$ Pedoman Kerja Rencana Jihad 20102015. Bandung 2010.

Qaradawi, Yusuf al-. Pengantar Studi Hadits. Penerj. Agus Suyadi Raharusun dan Dede Rodin. CV. Pustaka Setia. Bandung. 2007.

Bagaimana Memahami Hadits Nabi Saw. penj: Muhammad AlBaqir, Bandung: Karisma. 1999

Saefuddin, Encang. Fiqhud Da'wah. Mujahid Press. Bandung. 2014

Shofwan, Wawan dkk. Makmum Masbuq Mendapat ruku' Imam. Tim sekretariat Dewan Hisbah Persatuan Islam. Bandung. 2006.

Sholehuddin, Wawan Shofwan. Kumpulan Keputusan Sidang Dewan Hisbah Persis tentang Akidah dan Ibadah, Bandung: Persis Pers, 2008.

Sudrajat, Enang dkk. Kementrian Agama RI. Al-Quran Tajwid dan Terjemahnya. PT. Sygma Examedia Arkanleema.2007

Suparta, Munzier, dan Utang Ranuwijaya. Ilmu Hadis. Jakarta: PT. Raja Grafindo Persada, 1996.

Syarief, Nashruddin. Al-Istidlal bi Al-Hadits, Dewan Hisbah Persatuan Islam. 2014

Umar, Atho'illah. Budaya Kritik Ulama Hadits. Analisa Historis dan Praktis. Jurnal Mutawatir No. 1. Vol. 1. Jan-Juni. 2011. IAIN Sunan Ampel Surabaya.

Umarie, Barmawie. Status Hadis Sebagai Dasar Tasyri'. Sala: Penerbit. AB. Siti Sjamsiyyah, 1963.

Usman, Iskandar. Istihsan dan Pembaharuan Hukum Islam. Jakarta: PT. Raja Grafindo Persada, 1994.

Wildan, Dadan. Sejarah Perjuangan Persis. 1923-1983. Bandung: Gema Syahida. Bandung. 1995.

Zakaria, Aceng. Thuruq Al-Istinbath Dewan Hisbah Persatuan Islam, Bandung : Persis Pers. 2007

Zakaria, A. Al-Hidayah. Edisi Kompilasi. Garut: Ibn Azka Press, 2006. 
